\title{
PENGARUH LEADER MEMBER EXCHANGE (LMX) TERHADAP HUBUNGAN ANTARA PARTISIPASI ANGGARAN, KINERJA MANAJERIAL, DAN KEPUASAN KERJA
}

\section{EFFECT OF LEADER MEMBER EXCHANGE (LMX) TOWARD RELATIONSHIP BETWEEN BUDGET PARTICIPATION, MANAGERIAL PERFORMANCE, AND WORK SATISFACTION}

\author{
F. Susandra, M. N. Afif \\ Program Studi Akuntansi Fakultas Ekonomi Universitas Djuanda, Bogor \\ E-mail : farizka.susandra@unida.ac.id_m.nur.afif @unida.ac.
}

\begin{abstract}
Supervisor subordinate relationship in this study were analyzed using the Leader Member Exchange (Graen et al., 1982). This study purposed to empirically examine the moderating effect Leader Member Exchange on the relationship budgetary participation and managerial performance, as well as examine the direct and indirect effect of budgetary participation, managerial performance, and job satisfaction. Survey methods used in this study with 123 participants consisting of mid-level managers in Bandar Lampung's BUMN/D and BUMS. The results of this study indicate that budgetary participation is directly related to managerial performance and job satisfaction. Managerial performance was found to partially mediate the relationship budgetary participation and job satisfaction. In addition, there is a pretty interesting findings that a low correlation subordinate supervisor can increase budgetary participation and managerial performance, while high correlation subordinate supervisor can reduce the level of budgetary participation and managerial performance manager.
\end{abstract}

\section{Keywords: Budget Participation, Job Satisfaction, Leader Member Exchange, Managerial} Performance

\begin{abstract}
ABSTRAK
Hubungan bawahan atasan dalam penelitian ini dianalisis menggunakan Leader Member Exchange (Graen et al., 1982). Penelitian ini bertujuan untuk menguji secara empiris pengaruh moderasi Leader Member Exchange pada hubungan partisipasi penyusunan anggaran dan kinerja manajerial, serta menguji pengaruh langsung dan tidak langsung dari partisipasi anggaran, kinerja manajerial, dan kepuasan kerja. Metode survei yang digunakan dalam penelitian ini dengan 123 peserta yang terdiri dari manajer tingkat menengah di BUMN / D dan BUMS Bandar Lampung. Hasil penelitian ini menunjukkan bahwa partisipasi anggaran terkait langsung dengan kinerja manajerial dan kepuasan kerja. Kinerja manajerial ditemukan untuk menengahi hubungan partisipasi partisipasi anggaran dan kepuasan kerja. Selain itu, ada temuan yang cukup menarik bahwa supervisor bawahan berkorelasi rendah dapat meningkatkan partisipasi anggaran dan kinerja manajerial, sementara supervisor bawahan korelasi tinggi dapat mengurangi tingkat partisipasi anggaran dan manajer kinerja manajerial.
\end{abstract}

\section{Kata kunci: Partisipasi Anggaran, Kepuasan Kerja, Pertukaran Anggota Pemimpin,} Kinerja Manajerial 


\section{PENDAHULUAN}

Lebih dari 50 tahun yang lalu, Argyris menemukan bukti empiris bahwa keterlibatan seseorang dalam penyusunan anggaran dapat mempengaruhi perilakunya dalam lingkup pekerjaan. Afif dan Rismawati (2019) menjelaskan bahwa hasil penelitian Argyris menyatakan tekanan yang dihadapi karyawan dalam pencapaian target anggaran mampu menghasilkan perilaku disfungsional seperti ketegangan kerja dan rendahnya motivasi karyawan yang dapat mengakibatkan turunnya kinerja individual. Beberapa teori yang sering digunakan untuk menjelaskan fenomena anggaran yaitu teori keagenan, teori pencapaian tujuan, dan teori kontingensi.

Teori keagenan dalam partispasi anggaran umumnya menguji hubungan estimasi yang bias dalam penganggaran (budgetary slack). Agen mengharapkan kompensasi insentif terhadap pekerjaannya. Kompensasi agen terkait langsung dengan capaian tujuan dan anggaran, maka agen cenderung berperilaku disfungsional untuk bermain dalam anggaran melalui partisipasi (Andison dan Augustine,2017). Teori pencapaian tujuan dalam partisipasi anggaran umumnya menguji hubungan internalisasi tujuan, komitmen, dan kinerja (Ermawati, 2017). Teori kontingensi pada umumnya menguji mekanisme organisasi seperti lintas tugas fungsional atau sistem organisasi yang akan dinegosiasi terhadap harga transfer dan partisipasi anggaran untuk koordinasi organisasi dan meningkatkan efektifitas (Gutama et.al, 2015).

Partisipasi anggaran memiliki hubungan terhadap kinerja manajerial dan kepuasan kerja, hal ini didasarkan atas pernyataan normatif (Hutama dan Goenawan,2017) Berbagai teori digunakan untuk menjelaskan hubungan antara partisipasi anggaran dan kinerja manajerial, namun hasil penelitian empiris menunjukkan hasil yang beragam dan tidak konsisten (Lasmana dan Ashariah,2019). Berikut contoh hasil penelitian terdahulu mengenai hubungan partisipasi anggaran dan kinerja manajerial yang dikutip dari penelitian Nazaruddin dan Setyawan (2016): Partisipasi anggaran, kinerja, dan kepuasan kerja menunjukkan hubungan positif (Oktavianda dan Iqbal, 2018).

Partisipasi anggaran merupakan metode yang cukup moderat dengan melibatkan peran atasan dan bawahan. Pemimpin memiliki peran penting untuk memotivasi keterlibatan manajer dalam penyusunan anggaran, dan memantau kinerja serta kepuasan kerja manajer. Gaya kepemimpinan termasuk dalam salah satu faktor kontingensi yang dapat menjelaskan lebih baik hubungan antara partisipasi anggaran, kinerja manajerial, dan kepuasan kerja (Sukmantar dan Wirasedana, 2015). Pendekatan kepemimpinan yang digunakan pada penelitian-penelitian terdahulu hanya melihat dari perspektif pemimpin. Savitri,et.al, (2015) berasumsi seolah-oleh pemimpin memperlakukan semua karyawan dengan sikap yang sama. Perlakuan berbeda-beda yang terjalin antara pemimpin dan setiap bawahan dimungkinkan dapat terjadi di dalam sebuah organisasi. Perbedaan sikap inilah yang menjadi dasar teori pertukaran pemimpin-anggota atau Leader Member Exchange Theory (seterusnya disingkat LMX).

Hasil empiris interaksi gaya kepemimpinan dan partisipasi anggaran tidak konsisten. Hasil analisis Susandra dan Gandara (2017) yang dapat menjelaskan hubungan signifikan adanya pengaruh interaksi gaya kepemimpinan dan partisipasi anggaran terhadap kinerja dan kepuasan kerja. Hal ini dimungkinkan bahwa gaya kepemimpinan merupakan faktor kontingensi yang perlu diuji pada situasi dan kondisi yang berbeda.

Penelitian ini bertujuan menguji pengaruh langsung dan tidak langsung hubungan partisipasi anggaran, kinerja manajerial, dan kepuasan kerja. Yuniarti 
dan Satya (2019) tidak menguji hubungan antara kinerja dan kepuasan kerja, hal ini dikarenakan terdapat penelitian terdahulu yang menyatakan bahwa tidak ada hubungan antara kinerja dan kepuasan kerja (Afif dan Rismawati, 2019). Teori pengharapan (expectancy theory) menyatakan bahwa seseorang yang memiliki kinerja yang baik akan mengharapkan penghargaan atas usahanya, sehingga dia puas akan hasil yang telah di capai (Lasmana dan Ashariah,2019).

Selain itu, penelitian ini menguji tingkat LMX yang akan memoderasi hubungan antara partisipasi anggaran terhadap kinerja manajerial. LMX sebagai variabel yang menghubungkan keterkaitan dengan partisipasi anggaran, kinerja manajerial, dan kepuasan kerja belum pernah diteliti sebelumnya. Kegagalan Andison dan Augustine (2017). dalam menguji peran moderasi gaya kepemimpinan dapat disebabkan oleh konsep dari gaya kepemimpinan itu sendiri. Konsep gaya kepemimpinan yang dipilih oleh Hutama dan Goenawan (2017) yaitu gaya transformasional dan gaya transaksional. Kedua gaya kepemimpinan tersebut menggambarkan bahwa seolaholah perilaku pemimpin sudah terstandar oleh pola kepemimpinan transaksional dan transformasional. Penelitian ini memilih konsep LMX yang cenderung kepada pembentukan pola kepemimpinan berdasarkan perilaku pemimpin.

Penelitian ini diharapkan memberikan kontribusi dalam pengembangan teori konsep kepemimpinan yang dikaitkan dengan partisipasi angaran. Penelitian ini juga dapat digunakan sebagai bahan pertimbangan pengimplementasian gaya kepemimpinan dan hubungan kedekatan yang terjalin antara atasan-bawahan. Pertimbangan pengimplementasian gaya kepemimpinan tersebut merupakan faktor penting yang akan mempengaruhi kinerja dan kepuasan kerja karyawan.

Artikel ini disusun sebagai berikut, pokok bahasan berikutnya adalah tinjauan teori dan pengembangan hipotesis, dilanjutkan metoda penelitian untuk menguji hipotesis dan laporan hasil pengujian. Artikel ini ditutup dengan kesimpulan dan saran untuk penelitian selanjutnya.

\section{TEORI DAN PENGEMBANGAN HIPOTESIS \\ Anggaran}

Menurut Savitri.et.al, (2015) anggaran adalah suatu rencana terinci yang dinyatakan secara formal dalam ukuran kuantitatif, biasanya dalam satuan uang, untuk menunjukkan perolehan dan penggunaan sumber-sumber suatu organisasi dalam jangka waktu tertentu, biasanya satu tahun. Anggaran berfungsi sebagai rencana finansial masa depan, selain itu juga berfungsi sebagai alat sistem pengendalian dan evaluasi kinerja (Adler dan Reid, 2008).

\section{Partisipasi Anggaran}

Tiga pendekatan dalam proses penyusunan anggaran menurut Susandra dan Gandara (2017) yaitu top-down (pendekatan dari atas ke bawah), bottomup (pendekatan dari bawah ke atas) dan pendekatan partisipasi. Penggunaan pendekatan proses penyusunan anggaran biasanya disesuaikan dengan kebutuhan dan kebijakan organisasi. Menurut Ermawati (2017) partisipasi anggaran berpedoman pada sejauh mana manajer berpartisipasi dalam persiapan proses penganggaran dan memengaruhi sasaran anggaran pada pusat pertanggung jawaban.

\section{Kinerja Manajerial}

Kinerja manajerial adalah ukuran seberapa efektif dan efisien manajer telah bekerja untuk mencapai tujuan organisasi berdasar pada kemampuan manajer dalam pelaksanaan tugas manajerialnya seperti perencanaan, investigasi, koordinasi, evaluasi, pengawasan, penataan staf, negosiasi, dan perwakilan.

\section{Kepuasan Kerja}

kepuasan kerja adalah sikap umum terhadap pekerjaan seseorang yang menunjukkan perbedaan antara jumlah penghargaan yang diterima pekerja dan 
jumlah yang mereka yakini seharusnya mereka terima. Terdapat dua unsur penting dalam kepuasan kerja, yaitu nilai-nilai pekerjaan dan kebutuhan-kebutuhan dasar.

\section{Teori Kontingensi}

Fungsi sistem akuntansi manajemen salah satunya adalah menyediakan informasi untuk membantu manajer dalam mengendalikan aktivitasnya, serta mengurangi ketidakpastian lingkungan dalam mencapai tujuan organisasi. Pendekatan teori kontingensi mengidentifikasi bentuk-bentuk optimal pengendalian organisasi di bawah kondisi operasi yang berbeda dan mencoba untuk menjelaskan bagaimana prosedur operasi pengendalian organisasi tersebut.

\section{Leader Member Exchange}

LMX merupakan suatu sistem kesatuan dan hubungan yang meliputi kedua pihak, mencakup pola perilaku yang saling tergantung antara yang satu dengan yang lainnya dan saling berbagi alat untuk menghasilkan outcome serta menghasilkan konsep mengenai lingkungan, pola sebabakibat, dan nilai-nilai. Terdapat tiga domain yang menjadi dasar dalam membangun hubungan pada LMX yaitu rasa hormat, kepercayaan dan kewajiban. Hubungan antar atasan dan bawahan tidak dapat terbentuk tanpa adanya saling menghormati (respect) terhadap kemampuan orang lain, tanpa adanya rasa percaya yang timbal balik dengan yang lain, dan tidak memperkirakan bahwa pengaruh kewajiban dapat berkembang menjadi suatu hubungan kerja.

\section{Definisi Operasional dan Pengukuran Variabel}

\section{Partisipasi Anggaran}

Partisipasi anggaran merupakan tingkat keterlibatan manajer dalam penyiapan anggaran kegiatan yang menjadi tanggung jawabnya. Partisipasi anggaran diukur dengan menggunakan instrumen daftar pertanyaan. Konstruk partisipasi anggaran terdiri dari enam indikator yaitu: pengaturan anggaran, revisi anggaran, frekuensi berhubungan dengan anggaran, pengaruh jumlah anggaran akhir, pentingnya kontribusi anggaran, dan frekuensi diskusi anggaran. Alternatif jawaban atas daftar pertanyaan tersebut menggunakan skala likert 5 poin dengan rentang nilai satu (sangat rendah) sampai dengan lima (sangat tinggi).

\section{Kinerja Manajerial}

Kinerja manajerial merupakan hasil upaya yang dilakukan manajer dalam melakukan tugas dan fungsinya dalam organisasi. Kinerja manajerial diukur dengan menggunakan instrumen daftar pertanyaan. Daftar pertanyaan tersebut terdiri dari sembilan butir pertanyaan yang digunakan untuk mengevaluasi kinerja responden. Kinerja manajerial dalam penelitian ini diukur dengan sembilan indikator kinerja yaitu: perencanaan, investigasi, pengkoordinasian, evaluasi, pengawasan, penataan staf, negosiasi, dan perwakilan, representasi, dan penilaian kinerja secara keseluruhan. Alternatif jawaban atas daftar pertanyaan tersebut menggunakan skala likert 5 poin dengan rentang nilai satu (sangat rendah) sampai dengan lima (sangat tinggi).

\section{Kepuasan Kerja}

Kepuasan kerja merupakan sikap dan perasaan positif dalam diri seseorang terhadap pekerjaannya. Kepuasan kerja diukur dengan menggunakan Minnesota Satisfaction Questioner (MSQ). Konstruk kepuasan kerja terdiri dari 20 pertanyaan sesuai konsep MSQ meliputi kepuasan intrinsik dan ekstrinsik seseorang terhadap pekerjaannya. Alternatif jawaban atas daftar pertanyaan tersebut menggunakan skala likert 5 poin dengan rentang nilai satu (sangat tidak setuju) sampai dengan lima (sangat setuju).

\section{LMX (Leader Member Exchange)}

LMX adalah pola kepemimpinan yang terbentuk karena hubungan kedekatan yang terjalin antara atasan dan bawahan. Konstruk LMX diadopsi dari penelitian Graen et al. (1982). Instrumen ini terdiri atas tujuh item pertanyaan. Alternatif jawaban atas daftar pertanyaan tersebut menggunakan skala likert 5 poin dengan 
rentang nilai satu (sangat tidak setuju) sampai dengan lima (sangat setuju). Pengelompokkan grup ditentukan dengan batas nilai tengah dari total jumlah poin terbesar.

\section{PENGEMBANGAN HIPOTESIS}

Teori agensi menyiratkan adanya ketimpangan informasi atau asimetri informasi antara agen dan prinsipal (Christensen, 1982). Menurut teori ini, bawahan cenderung enggan untuk mengungkapkan informasi mengenai tanggung jawab yang dimilikinya kepada atasan mereka kecuali jika atasan memberikan insentif untuk melakukannya. partisipasi anggaran memungkinkan bawahan untuk mengungkapkan informasi pribadi mereka, yang mengarah pada kinerja yang lebih baik dan keuntungan ekonomi bagi perusahaan.

Ermawati (2017) menyatakan bahwa partisipasi anggaran yang tinggi akan meningkatkan kinerja manjerial ketika pegawai yang dilibatkan dalam penyusunan anggaran. Penelitian yang dilakukan dengan cara mengirimkan kuesioner yang melibatkan 37 manajer departemen personalia, operasi, dan pemasaran dari berbagai perusahaan manufaktur di Hongkong menunjukkan hasil adanya hubungan yang signifikan antara partisipasi anggaran dan kinerja manjerial. Partisipasi anggaran dapat memotivasi bawahan, mengidentifikasi, dan melakukan negosiasi dengan atasan mengenai target anggaran, menerima kesepakatan anggaran dan melaksanakannya, sehingga dapat menghidarkan dampak negatif anggaran.

\section{H1: Partisipasi anggaran berpengaruh positif terhadap kinerja manajerial.}

Kepuasan kerja adalah tingkat afeksi positif seorang pekerja terhadap pekerjaan dan situasi pekerjaan. Afeksi positif tersebut berlangsung dalam aspek kognitif dan perilaku. Aspek kognitif kepuasan kerja adalah keyakinan pekerja bahwa pekerjaannya menarik. Aspek perilaku kepuasan kerja adalah kecenderungan perilaku pekerja atas pekerjaannya yang ditunjukkan lewat pekerjaan yang dilakukan, terus bertahan di posisinya, atau bekerja secara teratur dan disiplin. Berdasarkan teori pengharapan, penghargaan menyebabkan kepuasan dan bahwa dalam beberapa hal kinerja menghasilkan penghargaan.

Ermawati, (2017) menyatakan bahwa kepuasan akan meningkat jika kinerja meningkat. Penelitian menunjukkan hubungan positif yang terbangun diantara kinerja dan kepuasan kerja. Penelitian lain yang menemukan hubungan positif antara kinerja dan kepuasan yaitu kinerja yang baik akan meningkatkan kepuasan kerja manajer.

\section{H2: Kinerja Manajerial berpengaruh positif terhadap kepuasan kerja.}

Penelitian-penelitian mengenai hubungan antara partisipasi anggaran dan kepuasan kerja masih sedikit. Penelitianpenelitian yang menunjukkan adanya pengaruh antara partisipasi anggaran dan kepuasan kerja diantaranya yaitu adanya hasil yang positif terhadap hubungan antara partisipasi anggaran dan kepuasan kerja yang diujikan kepada para manajer di Mexico. Hubungan partisipasi anggaran dan kepuasan kerja dalam kenyataannya merupakan hubungan yang kompleks. Berdasarkan hal tersebut tidak tertutup kemungkinan bahwa ada faktor-faktor lain yang dapat menjelaskan lebih baik hubungan antara partisipasi anggaran dan kepuasan kerja.

Keterlibatan manajer dalam penyusunan anggaran menimbulkan keyakinan dan rasa bertanggung jawab terhadap pekerjaannya. Rasa tanggung jawab tersebut diimplimentasikan dalam bentuk pelaksanaan fungsi-fungsi dan kewajiban manajerial. Pencapaian kerja yang didapatkan manajer setelah dilaksanakan tugas-tugas sesuai dengan apa yang diharapkan akan menimbulkan rasa puas dan sikap positif terhadap pekerjaannya. 
H3: Partisipasi anggaran berpengaruh tidak langsung terhadap kepuasan kerja dengan dimediasi oleh kinerja manajerial.

Seorang pemimpin
kenyataannya dalam
memperlakukan atau memotidak
bawahannya dengan cara yang sama
mengungkapkan bahwa fokus dari
hubungan pimpinan dan bawahan
dimaksudkan untuk memaksimumkan
keberhasilan organisasi melalui interaksi
kedua belah pihak. Hubungan kedekatan
antara atasan dan bawahan ini terjadi
karena adanya keterbatasan waktu
sehingga pemimpin akan memberikan

kepercayaan dan kesempatan terlibat dalam kegiatan perusahaan lebih banyak pada sekelompok orang.

Penelitian yang menghubungkan interaksi antara partisipasi anggaran dan gaya kepemimpinan LMX yang dikaitkan dengan kinerja manajerial belum ada, namun ada beberapa penelitian yang dikutip menyatakan bahwa tingkat LMX yang tinggi (in group) lebih berpeluang mampu meningkatkan kinerja dibandingkan dengan LMX yang rendah (out group).

H4: LMX sebagai variabel pemoderasi memengaruhi hubungan antara partisipasi anggaran terhadap kinerja manajerial.

Gambar 1

Model Penelitian

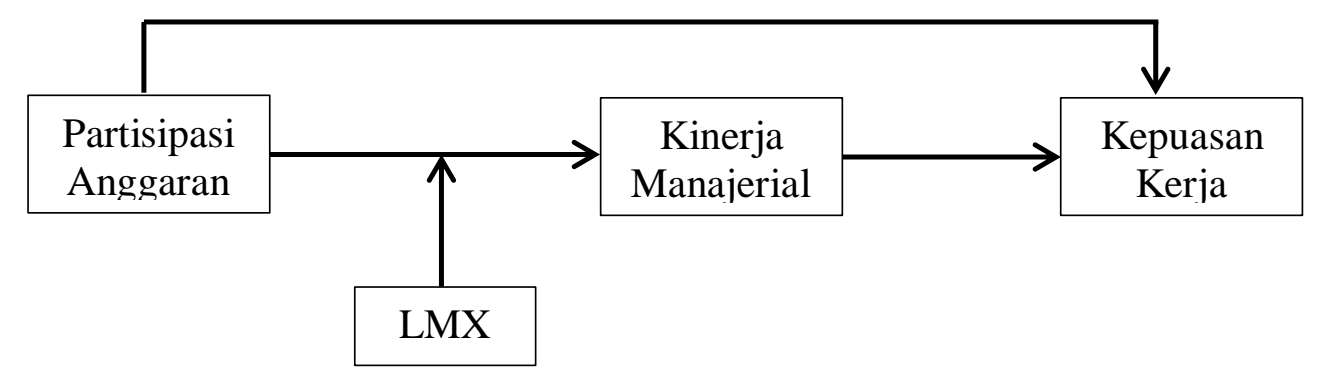

IV. METODA PENELITIAN

Populasi dan Sampel

Populasi dalam penelitian ini adalah manajer tingkat menengah pada perusahaan BUMN/D dan BUMS. Sampel penelitian yaitu manajer tingkat menengah pada perusahaan BUMN/D dan BUMS yang tersebar di wilayah Bandar Lampung.

Tabel 1. Karakteristik Responden

\begin{tabular}{lll}
\hline Karakteristik Responden & Jumlah & Persentase \\
\hline Jenis kelamin & & \\
Laki-laki & 103 & $83,74 \%$ \\
Perempuan & 20 & $16,26 \%$ \\
Jumlah & 123 & $100 \%$ \\
& & \\
\hline Usia & & \\
25 - 35 Tahun & 10 & $8,13 \%$ \\
36 - 45 Tahun & 42 & $34,15 \%$ \\
46 - 55 Tahun & 65 & $52,84 \%$ \\
56 - 65 Tahun & 6 & $4,88 \%$ \\
Diatas 65 Tahun & 0 & $0 \%$ \\
Jumlah & 123 & $100 \%$
\end{tabular}




\begin{tabular}{lll}
\hline Pendidikan & & \\
D3 & 0 & $0 \%$ \\
S1 & 101 & $82,11 \%$ \\
S2 & 22 & $17,89 \%$ \\
S3 & 0 & $0 \%$ \\
Jumlah & 123 & $100 \%$ \\
& & \\
\hline Lama Bekerja & & \\
0-1 Tahun & 0 & $0 \%$ \\
1-5 Tahun & 1 & $0,81 \%$ \\
5-10 Tahun & 31 & $25,20 \%$ \\
Lebih dari 10 Tahun & 91 & $73,99 \%$ \\
Jumlah & 123 & $100 \%$ \\
\hline
\end{tabular}

Sumber: Data diolah (2015)

\section{Metode Pengumpulan Data}

Metode pengumpulan data dalam penelitian ini adalah melalui survei. Kuesioner digunakan sebagai alat komunikasi untuk mendapatkan jawaban. Jumlah kuesioner yang disebarkan dalam penelitian ini sebanyak 600 kuesioner. Kuesioner yang diisi dan dikembalikan sebanyak 127 dengan rincian empat kuesioner tidak dapat digunakan karena diisi tidak lengkap. Kuesioner yang dapat diolah adalah 123 kuesioner.

\section{Variabel Penelitian}

Penelitian ini terdiri dari empat variabel yang membangun sebuah model yaitu partisipasi anggaran, kinerja manajerial, kepuasan kerja, dan LMX. Satu variabel adalah variabel independen atau eksogen yaitu partisipasi anggaran. Variabel dependen atau endogen yaitu kinerja manajerial dan kepuasan kerja. Kinerja manajerial memiliki peran ganda yaitu sebagai variabel dependen (endogen) dan variabel mediasi. LMX merupakan variabel moderasi.

\section{Metoda Analisis}

Pengujian hipotesis dalam penelitian ini menggunakan SEM (Structural Equation Modeling). Alat analisis SEM yang digunakan adalah SEM PLS (Partial Least Squares) WarpPLS 3.0. Langkahlangkah menguji hipotesis menggunakan dua model, model pengukuran (outer model) dan model struktural (inner model) (Hartono, 2011).

\section{HASIL PENELITIAN \\ Bias Tidak Merespon}

Pengujian bias tidak merespon pada penelitian ini dilakukan untuk membandingkan kelompok sampel berdasarkan waktu pengembalian kuesioner. Waktu pengembalian kuesioner dibedakan dengan jangka waktu yaitu 1 minggu, 2 minggu, 3 minggu, dan 4 minggu. Analisis statistik yang digunakan untuk menguji bias tidak merespon berdasarkan perbedaan waktu pengembalian yaitu Uji Kruskal-Wallis. Uji Kruskal-Wallis adalah uji nonparametrik untuk membandingkan tiga atau lebih kelompok data sampel. Program statistik yang digunakan yaitu SPSS 21 . nilai signifikansi masing-masing konstruk pada minggu yang berbeda diatas alpha ( $\operatorname{sig}>\alpha ; \alpha=0,05)$. Hasil menunjukkan bahwa tidak ada bias tidak merespon berdasarkan perbedaan waktu pengembalian kuesioner penelitian. 
Tabel 2 Tabel Pengujian Kruskal-Wallis

\begin{tabular}{lcccc}
\hline Keterangan & Minggu & N & Mean Rank & Sig. \\
\hline PA & 1 & 18 & 72,67 & 0,300 \\
& 2 & 45 & 55,88 & \\
& 3 & 23 & 59,02 & \\
& 4 & 37 & 66,11 & 0,061 \\
KM & Total & 123 & & \\
& 1 & 18 & 65,89 & \\
& 2 & 45 & 52,31 & \\
& 3 & 23 & 76,24 & \\
\hline KK & 4 & 37 & 63,04 & \\
& Total & 123 & & 0,121 \\
& 1 & 18 & 70,94 & \\
& 2 & 45 & 60,61 & \\
& 3 & 23 & 59,39 & \\
\hline LMX & 4 & 37 & 60,96 & \\
& Total & 123 & & \\
& 1 & 18 & 76,42 & \\
& 2 & 45 & 61,14 & \\
& 3 & 23 & 66,89 & \\
& 4 & 37 & 52,99 & \\
& Total & 123 & & \\
\hline
\end{tabular}

Sumber: Data diolah (2015)

\section{Bias Metode Umum}

Pengujian bias metoda umum pada penelitian ini dilakukan dengan pengujian satu faktor yang dikembangkan oleh Hartmann Program statistik yang digunakan yaitu SPSS 21. Hasil terdapat lima faktor teratas yang memiliki nilai eigenvalues lebih besar dari 1 sehingga dapat disimpulkan bias metode umum tidak terjadi dalam penelitian ini.

Tabel 3. Tabel Pengujian One Factor

\begin{tabular}{|c|c|c|c|}
\hline \multirow{2}{*}{ Component } & \multicolumn{3}{|c|}{ Initial Eigenvalues } \\
\hline & Total & $\%$ of Variance & Cumulative \% \\
\hline 1 & 8,708 & 20,733 & 20,733 \\
\hline 2 & 3,794 & 9,034 & 29,767 \\
\hline 3 & 2,936 & 6,990 & 36,757 \\
\hline 4 & 2,323 & 5,532 & 42,289 \\
\hline 5 & 2,216 & 5,275 & 47,564 \\
\hline
\end{tabular}

Sumber: Data diolah (2015)

\section{Model Pengukuran}

Hasil pengujian menunjukkan bahwa indikator partisipasi anggaran yang dapat digunakan dalam penelitian ini adalah PA1, PA3, PA4, dan PA5. Indikator kinerja manajerial yang dapat digunakan dalam penelitian ini adalah KM2, KM4, KM5, dan KM7. Loading masing-masing indikator telah memenuhi syarat validitas konvergen yaitu diatas 0,6 dan signifikan.
Indikator kepuasan kerja yang dapat digunakan dalam penelitian ini adalah KK8, KK9, KK10, KK11, dan KK20. Indikator LMX yang dapat digunakan dalam penelitian ini adalah LMX1, LMX4, LMX5, dan LMX7. Nilai AVE telah memenuhi syarat diatas 0,5 , begitu juga nilai composite reliability lebih dari 0.7 dan nilai cronbach alpha lebih dari 0.7. Loading setiap indikator dalam konstruk 
yang tidak bernilai diatas 1 , full collin. VIF yang dibawah 3.3 menandakan tidak adanya indikator abnormalitas seperti kolinieralitas.

\section{Model Struktural}

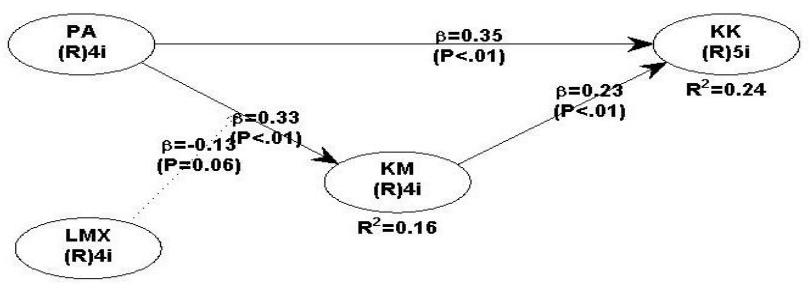

Gambar 2. Hasil Pengujian Model Leader Member Exchange, Partisipasi Anggaran, Kinerja Manajerial, dan Kepuasan Kerja

Sumber: Data diolah SEM WARP-Pls 3.0 (2015)

Gambar 2 menunjukkan bahwa pengaruh partisipasi anggaran terhadap kinerja manajerial adalah positif 0.33 dan signifikan $(\mathrm{p}<0.01)$. Pengaruh partisipasi anggaran terhadap kepuasan kerja adalah positif 0.35 dan signifikan $(\mathrm{p}<0.01)$. Pengaruh kinerja manajerial terhadap kepuasan kerja adalah positif 0.23 dan signifikan $(\mathrm{p}<0.01)$. Pengaruh LMX sebagai pemoderasi terhadap hubungan antara partisipasi anggaran dan kinerja manajerial adalah negatif 0.13 dan signifikan $(\mathrm{p}<0.1)$.

$\mathrm{R}^{2}$ untuk kinerja manajerial adalah 0.16 , menunjukkan bahwa variasi kinerja manajerial dapat dijelaskan sebesar $16 \%$ oleh variasi partisipasi anggaran dan moderasi LMX. $\mathrm{R}^{2}$ untuk kepuasan kerja adalah 0.24 , menunjukkan bahwa variasi kepuasan kerja dapat dijelaskan sebesar $24 \%$ oleh variasi partisipasi anggaran dan kinerja manajerial sebagai pemediasi.

Effek size dalam penelitian ini tergolong kelompok lemah dan medium. Effect size lemah menunjukkan bahwa norma-norma dalam penelitian ini memiliki peranan yang lemah dari perspektif praktis dan medium dari perspektif praktis. Model gambar 2 sudah fit karena nilai ARS signifikan dengan $\mathrm{p}=0.252$. Hasil terlihat pada tabel di bawah ini:

Tabel 4. Hasil Pengujian Model Fit Model Penelitian

\begin{tabular}{lll}
\hline Keterangan & Nilai & P-values \\
\hline APC & 0,26 & $<0,001$ \\
ARS & 0,20 & 0,006 \\
AVIF & 1,167 &
\end{tabular}

Sumber: Data diolah (2015)

\section{Pengujian Hipotesis}

Tabel 5. Koefisien Jalur (Path Coefficients, P Value)

\begin{tabular}{lrr}
\hline \multicolumn{1}{c}{ Konstruk } & Path coefficients & \multicolumn{1}{c}{ P-value } \\
\hline PA-KM & 0,37 & $<0,001^{* * *}$ \\
KM-KK & 0,37 & $<0,001^{* * *}$ \\
PA-KK & 0,44 & $<0,001^{* * *}$ \\
PA-KK (indirect effect) & 0,35 & $<0,001^{* * *}$ \\
LMX*PA & $-0,13$ & $0,06^{*}$ \\
\hline
\end{tabular}


Ket: PA (Partisipasi Anggaran); KM (Kinerja Manajerial); KK (Kepuasan Kerja); LMX (Leader Member Exchange). * $\mathrm{p}<0.10 ; * * \mathrm{p}<0.05 ; * * * \mathrm{p}<0.01$

\section{Sumber: Data diolah (2015)}

Tabel 5 menunjukkan bahwa terdapat hubungan positif antara partisipasi anggaran terhadap kinerja manajerial yang ditunjukkan dengan nilai koefisien beta sebesar 0.37 dan nilai signifikansi $<0.001$. Hal ini menunjukkan bahwa hipotesis 1 terdukung. Terdapat hubungan positif antara kinerja manajerial dan kepuasan kerja yang ditunjukkan dengan nilai koefisien beta sebesar 0.37 dan nilai signifikansi $<0.001$. Hal ini menunjukkan bahwa hipotesis 2 terdukung. Hasil menunjukkan adanya penurunan koefisien beta pada hubungan langsung partisipasi anggaran terhadap kinerja dari 0.44 menjadi 0.35 dengan nilai signifikansi tetap yaitu $<0.001$. Hal ini menunjukkan bahwa hipotesis 3 terdukung. Kinerja manajerial dalam penelitian ini hanya menjadi variabel pemediasi parsial, hal ini dikarenakan nilai signifikansi pada hubungan tidak langsung partisipasi anggaran dan kepuasan kerja tidak berubah menjadi tidak signifikan. LMX ditunjukkan dengan nilai koefisien jalur LMX sebesar -0.13 dan nilai signifikansi 0.06 dapat memberikan pengaruh berkebalikan atau negatif untuk hubungan partisipasi anggaran dan kinerja manajerial. Hal ini menunjukkan bahwa hipotesis 4 terdukung.

\section{Diskusi}

Hasil penelitian ini sesuai dengan hasil penelitian sebelumnya yang dilakukan oleh Adler dan Reid (2018). Terdukungnya hipotesis 1 menunjukkan bahwa partisipasi seorang manajer dalam penyusunan anggaran dapat meningkatkan kinerjanya dalam fungsi manajerial. Keterlibatan manajer dalam proses penyusunan anggaran, kontribusi ide dan pemikiran yang diberikan ternyata mampu mempengaruhi secara positif kinerja manajerialnya.

Hasil pengujian menunjukkan bahwa data empiris mendukung hipotesis 2, yaitu kinerja manajerial berpengaruh positif terhadap kepuasan kerja. Hasil penelitian ini sesuai dengan hasil-hasil penelitian sebelumnya yang dilakukan oleh Cherrington et al. (2015) Penelitian Adler dan Reid (2008) tidak melakukan pengujian hubungan antara kinerja manajerial dan kepuasan kerja, hal ini dikarenakan hubungan kedua variabel tersebut dinyatakan semu oleh sebagian peneliti.

Hasil pengujian menunjukkan bahwa data empiris mendukung hipotesis 3 , yaitu kinerja manajerial sebagai variabel pemediasi mempengaruhi secara positif dan parsial hubungan antara partisipasi anggaran terhadap kepuasan kerja. Hasil penelitian ini sesuai dengan hasil-hasil pernyataan premis sebelumnya tidak melakukan pengujian hubungan mediasi kinerja manajerial terhadap hubungan partisiapsi anggaran dan kepuasan kerja.

Hasil pengujian menunjukkan bahwa data empiris mendukung hipotesis 4 , yaitu LMX dapat memoderasi hubungan antara partisipasi anggaran dan kinerja manajerial. Hasil pengujian LMX cukup mengejutkan karena hasilnya bertentangan dengan yang menyatakan bahwa LMX yang tinggi mampu meningkatkan kinerja. Hal ini mungkin disebabkan oleh karakteristik budaya yang berbeda dari kelompok masyarakat yang berbeda, namun kecurigaan ini perlu dilakukan pengujian dimasa depan.

\section{KESIMPULAN, IMPLIKASI, DAN KETERBATASAN}

Manajer akan meningkatkan upayanya dalam berpatisipasi untuk penyusunan anggaran jika LMX yang diterima dari pimpinan rendah. LMX yang rendah mungkin dapat memicu rasa kompetitif untuk lebih menunjukkan potensi serta usaha yang lebih baik dalam menjalankan tugas-tugas manajerialnya, sehingga hal 
tersebut mampu meningkatkan kinerja manajerial dan kepuasan kerja.

Hasil penelitian ini dapat menjadi pertimbangan bagi para pimpinan BUMN/BUMD serta BUMD yang berada di Lampung bahwa kedekatan hubungan atasan bawahan yang terbentuk di dalam organisasi dapat membawa dampak negatif bagi kinerja bawahannya. Penelitian ini menyiratkan bahwa pemimpin yang memperlakukan manajernya secara berbeda-beda harus lebih bijaksana dan berhati-hati dalam penerapannya, hal ini dimaksudkan untuk menghindari efek negatif yang dapat ditimbulkan oleh hubungan kedekatan tersebut.

Penelitian ini memiliki keterbatasanketerbatasan yang dapat diperhatikan bagi pembaca maupun peneliti selanjutnya agar tidak mengulangi hal yang sama. Sampel penelitian ini terbilang kecil sehingga tidak dapat diuji dengan alat statistik yang lebih kompleks dalam pengujian model fit, sebaiknya sampel yang lebih besar akan dapat meningkkatkan validitas hasil penelitian. Observasi dilakukan pada satu daerah sehingga perlu kehati-hatian dalam mengeneralisasi hasil penelitian, sebaiknya observasi dilakukan pada beberapa daerah agar lebih baik dalam mengeneralisasi hasil penelitian. LMX hanya menggunakan persepsi manajer, akan lebih baik jika menambahkan persepsi dari pimpinan perusahaan karena LMX sejatinya merupakan pengelompokkan berdasarkan persepsi atasan dan bawahan. Pemilihan metode survey merupakan metode yang sederhana dan memiliki banyak kekurangan sehingga akan lebih baik jika menggabungkan metode survey dan wawancara untuk meningkatkan validitas hasil penelitian.

\section{DAFTAR PUSTAKA}

Adler, R. W. dan J. Reid. 2008. The effects of leadership style and budget participation on job satisfaction and job performance. Asia-Pacific

Management
Accounting Journal Vol. 3, No. 1, 21-46.

Afif, M. N., \& Rismawati, R. (2019). Analisis Harga Pokok Produksi Untuk Menentukan Harga Jual Produk Garment. JURNAL AKUNIDA, 5(1), 10-23.

Andison, A., \& Augustine, Y. (2017). Partisipasi Anggaran, Kepuasan Kerja, dan Kinerja Manajerial: Studi Pada Bisnis Keluarga Pempek di Kota Palembang. Esensi: Jurnal Bisnis dan Manajemen, 7(1), 73-82.

Cherrington, D. J., H. J. Reitz, dan W. E. Scott. 1971. Effects of contingent and noncontingent reward on the relationship between satisfaction and task performance. Journal of Applied Psychology Vol 55, No. 6, 531-536.

Ermawati, N. (2017). Pengaruh Partisipasi Anggaran terhadap Kinerja Manajerial dengan Motivasi Kerja sebagai Variabel Pemoderasi (Studi Kasus SKPD Kabupaten Pati). Jurnal Akuntansi Indonesia, 6(2), 141-156.

Gutama, G., Hermanto, M. C., Kaihatu, T. S., \& Kartika, E. W. (2015). Analisa Pengaruh Leadermember Exchange Terhadap Kepuasan Kerja Karyawan Melalui Perceived Organizational Support Sebagai Variabel Mediasi Di Restoran De Boliva Surabaya. Jurnal Hospitality dan Manajemen Jasa, 3(1), 256-268.

Handayani, E. T. T. W., Ilmi, Z., \& Azis, M. (2019). Pengaruh Partisipasi Anggaran terhadap Kinerja Manajerial dengan Self Efficacy, Desentralisasi dan 
Budaya Organisasi sebagai Variabel Pemoderasi pada Perbankan. Jurnal Ilmu Manajemen Mulawarman (JIMM), 3(2).

Harthantyo, Y., \& Rahardjo, M. (2017). Pengaruh Leader-Member Exchange (Lmx) Dan Percieved Organizational Support (Pos) Terhadap Komitmen Afektif (Studi Kasus Pada Karyawan Rumah Sakit Mekar Sari Bekasi). Diponegoro Journal of Management, 6(4), 1030-1042.

Hutama, P., \& Goenawan, R. (2017). Pengaruh Leader Member Exchange terhadap Kinerja Karyawan di Hotel X Surabaya. Jurnal Hospitality dan Manajemen Jasa, 5(2).

Lasmana, A., \& Ashariah, L. (2019). Prediksi Return Saham Pada Perusahaan Sektor Pertambangan Yang Terdaftar Di Bursa Efek Indonesia. JURNAL AKUNIDA, 5(1), 24-37.

Nazaruddin, I., \& Setyawan, H. (2016). Pengaruh Partisipasi Penyusunan Anggaran Terhadap Kinerja Aparat Pemerintah Daerah Dengan Budaya Organisasi, Komitmen Organisasi, Motivasi, Desentralisasi, Dan Job Relevant Information Sebagai Variabel Moderasi. Journal of Accounting and Investment, 12(2), 197-207.

Oktavianda, A. A., \& Iqbal, M. (2018). Pengaruh Leader Member Exchange (Lmx) Dan Motivasi Kerja Terhadap Loyalitas Karyawan (Studi Pada Karyawan Pt. Telekomunikasi Indonesia Tbk Witel Jatim Malang Selatan). Jurnal Administrasi Bisnis, 58(2), 179-187.
Savitri, E., Ritonga, K., \& Ayuni, R. (2015). Pengaruh Partisipasi AnggaranTerhadap Kinerja Manajerial Dengan Kepuasan Kerja Dan PengetahuanManajemen Biaya Sebagai Variabel Moderating. Jurnal Ilmiah Ekonomi dan Bisnis, 12(2), 166181.

Sukmantari, D. A. M. H., \& Wirasedana, I. W. P. (2015). Pengaruh Partisipasi Penganggaran Dan Komitmen Organisasi Pada Kinerja Manajerial Dengan Kepuasan Kerja Sebagai Variabel Intervening. E-Jurnal Akuntansi, 261-278.

Susandra, F., \& Gandara, I. (2017). Pengambilan Keputusan Keuangan Dengan Pendekatan Analisis Rasio Keuangan Pada Rsud Ciawi Kabupaten Bogor. JURNAL AKUNIDA, 3(1), 71-81.

Yuniarti, E., \& Satya, F. M. (2019). Pengaruh Komitmen Organisasi Dan Gaya Kepemimpinan Terhadap Hubungan Antara Partisipasi Anggaran Dan Kinerja Manajerial (Studi Empiris Pada Kantor Cabang Perbankan Di Propinsi Lampung). Jurnal Ilmiah ESAI, 2(1), 40-56. 